\title{
THE RELATIONSHIPS AMONG LEARNING INDEPENDENCE, REASONING ABILITY, AND LEARNING ENVIRONMENT AT HOME WITH STUDENTS MATHEMATICS LEARNING OUTCOMES IN CLASS XI TKJ OF EVEN SEMESTER IN SMK NEGERI 1 PLERET BANTUL
}

\author{
Nining Apriani ${ }^{a}$, Uswatun Khasanah ${ }^{\mathrm{b}}$ \\ Program Studi Pendidikan Matematika Universitas Ahmad Dahlan \\ Jalan Ring Road Selatan, Tamanan, Banguntapan, Bantul Yogyakarta \\ aniningapriani388@gmail.com, ${ }^{\mathbf{b}}$ uswatun.khasanah@pmat.uad.ac.id
}

\begin{abstract}
Learning mathematics is still considered difficult by most students, so the impact on learning outcomes. The lack of seriousness and independence of learning, reasoning ability is still low, and not all families have an adequate learning environment and conducive are several factors that may affect learning. Therefore, this study was conducted in order to determine whether or not a positive and significant between the relationship among learning independence, reasoning ability and learning environment at home with students mathematics learning outcomes in class XI TKJ of even semester in SMK Negeri 1 Pleret Bantul Regency at Academic Year 2015/2016. The population of this research was all students of class XI TKJ of even semester in SMK Negeri 1 Pleret Bantul in the academic year 2015/2016 consisting of 2 classes. As a sample class was class XI TKJ B by random sampling technique to the class. The data collection technique was performed by a method of testing and questionnaires. The questionnaire method used collection data learning independence and learning environment at home, as well as the test method used collection data on reasoning ability and mathematics learning the result of the student. Test data analysis requirements using the test for normality, independent, and the test for linearity. Data analysis for hypothesis testing using correlation analysis and linear regression analysis. The research result showed that there was a significant positive correlation between learning independence, reasoning ability and learning environment at home with students mathematics learning outcomes with $F_{\text {count }}=20,5041>F_{\text {table }}=2,96$. Multiple correlation coefficient $\left(\mathrm{R}^{2}\right)$ of 0,6950 with a regression equation $\hat{Y}=-19,56+0,4163 X_{1}+0,0999 X_{2}+0,6608 X_{3}$ with the relative contribution of $\left(X_{1}\right)=34,44 \%,\left(X_{2}\right)=8,64 \%,\left(X_{3}\right)=56,91 \%$, with coefficient of determination was $\left(R^{2}\right) 0,486$ and effective contribution $X_{1}=23,63 \%, X_{2}=62,55 \%$, dan $X_{3}=39,62 \%$.
\end{abstract}

Keywords: learning independence, reasoning ability, learning environment at home, mathematics learning outcomes

\section{INTRODUCTION}

Education is a supporting factor for the progress of a nation, let alone a nation that is still developing. Indonesia is a developing country so it needs an increase in human resources. As one of the basic sciences, mathematics has an important role in mastering science. Therefore education and teaching mathematics need special attention. Mathematics has an important role in daily life, both directly and indirectly. The human activity requires mathematical concepts and calculations. Mathematics is also one of the subjects taught in schools and includes subjects included in the National Examination. But there are still many students who think mathematics is a difficult subject, so it has an impact on learning outcomes. Learning mathematics is very influenced by several factors. The factors that influence learning are classified into two groups, namely internal factors, and external factors. Internal factors are factors that exist in individuals who are learning, while external factors are factors that exist outside the individual.

SMKN 1 Pleret in Bantul Regency as one of the vocational schools has the potential to compete with other vocational high schools. However, there are many obstacles that result in learning outcomes, especially in math subjects. Based on the data of the Final Semester Examination (UAS) obtained from the mathematics teacher of class XI TKJ of SMK Negeri 1 Pleret, Bantul Regency, it was found that out of 62 students most of the grades of students had not yet reached the Minimum completeness Criteria (75) 
in Mathematics applied in school. This shows that the mathematics learning outcomes of students are not maximal or still low.

Of the many influential factors, there are several factors that might influence the learning of class XI students of SMK Negeri 1 Pleret, Bantul, namely learning independence, reasoning ability, and learning environment at home. Learning independence is an active learning activity that is driven by the intention or motive to master a competency to overcome a problem, built with the knowledge or competence that is owned, both in determining the time of study, rhythm of learning, learning tempo, how to learn, and evaluation of learning done by the learner himself (Mujiman in Nurhayati, Eti, 2011: 61). Based on the interview of the writer with a mathematics teacher of class XI TKJ of SMK Negeri 1 Pleret, Bantul Regency on November 15, 2015, stated that mathematics is a subject that is considered difficult by most students. During the learning process, there are students who ask the teacher about the subject matter written on the board to be copied or not. In addition, when students are not given assignments or homework, most students do not work on existing practice questions. Some of these events indicate that student learning independence is still low due to a lack of self-awareness in terms of learning.

The success of someone in learning mathematics is also influenced by several factors from within, namely their ability to learn mathematics. That ability includes reasoning ability. According to Shadiq, Fadjar, (2004: 2), the reasoning is an activity, a process or an activity of thought to draw conclusions or make a new statement that is correct based on some statements whose truths have been proven or assumed before. One of the external factors that might influence learning is the learning environment. The home learning environment is the first learning environment for children to get things. The home learning environment plays an important role because most of the time students are at home, so parents know more about their children at home. A clean, comfortable and conducive environment can be a meaningful learning environment for student development.

This research is limited to the main issues concerning: 1) Learning independence, 2) The reasoning ability in this study is inductive and deductive reasoning ability on the subject of plane figure, 3) learning environment at home and 4) Learning outcomes obtained from the value of subject tests mathematics in class XI TKJ even semester SMK Negeri 1 Pleret Bantul Regency 2015/2016 academic year on the subject of plane figure. The purpose of this study was to determine whether or not there was a relationship between learning independence, reasoning ability and home learning environment with students' mathematics learning outcomes.

\section{METHODS}

The type of this research is a type of quantitative research with a population of all class XI TKJ in the even semester of SMK Negeri 1 Pleret, Bantul Regency in the 2015/2016 academic year, totaling 62 students consisting of 2 classes. Sampling is done by random sampling of classes. The sample of this study amounted to 31 students in class XI TKJ B. Data collection techniques used were questionnaire methods and test methods. Questionnaire for variable learning independence and learning environment at home. While the test for variable reasoning abilities and mathematics learning outcomes.

The instruments used were questionnaires and questions. Questionnaires are used to obtain learning independence data and home learning environments, while the questions are used to obtain data on reasoning abilities and mathematics learning outcomes on the subject of a plane figure. Before the instrument is tested in the research class so that the test questions of reasoning ability and learning outcomes are arranged not to deviate from the material being taught, then a grid is made, test questions, question questionnaires, and study items and test questionnaires. Instruments that have been compiled, then tested in the trial class first, namely class XI TKJ A. Then the test items were tested by validity test using product moment formula, different power using discrimination index formula, and reliability testing using the formula Kuder Richardson-20 ( KR-20). Analysis prerequisite test used a normality test, independent test, and linearity test. Data analysis using linear regression analysis and correlation analysis. In addition, a test was conducted to find out the relative contribution size and the effective contribution 
of learning independence, reasoning ability, and home learning environment with mathematics learning outcomes.

\section{RESULTS AND DISCUSSION}

Based on the research that has been carried out obtained data on learning independence, reasoning ability, home learning environment, and mathematics learning outcomes.

1. Normality Test

A normality test is used to test the distribution of data obtained on each variable with normal distribution or not. Based on the normality test that has been done, it is obtained that the four variables are normally distributed. The summary of the results of the normality test can be seen in Table 1.

Table 1. Normality Test Results

\begin{tabular}{|l|l|l|l|}
\hline No. & \multicolumn{1}{|c|}{ Variable } & \multicolumn{1}{c|}{$\chi_{\text {count }}^{2}$} & \multicolumn{1}{c|}{$\chi_{\text {table }}^{2}$} \\
\hline 1. & Learning independence $\left(\mathrm{X}_{1}\right)$ & 0,512 & 7,8147 \\
\hline 2. & Reasoning Ability $\left(\mathrm{X}_{2}\right)$ & 1,329 & 7,8147 \\
\hline 3. & Home Learning Environment $\left(\mathrm{X}_{3}\right)$ & 3,351 & 7,8147 \\
\hline 4. & Mathematics Learning Results $(\mathrm{Y})$ & 0,783 & 5,9915 \\
\hline
\end{tabular}

2. Independent Test

The independence test is used to determine the existence or absence of a relationship between independent learning independence variables $\left(\mathrm{X}_{1}\right)$ with the independent variable reasoning ability $\left(\mathrm{X}_{2}\right)$, the relationship between independent learning independence variables $\left(\mathrm{X}_{1}\right)$ and the independent variable at-home learning environment $\left(\mathrm{X}_{3}\right)$, the relationship between variables free reasoning ability $\left(\mathrm{X}_{2}\right)$ with independent variables at-home learning environment $\left(\mathrm{X}_{3}\right)$. Based on the independent tests that have been conducted, it was found that the three independent variables, learning independence and reasoning ability, learning independence and home learning environment, and reasoning ability and home learning environment, obtained that between variables are mutually independent or mutually independent. The summary of the results of independent tests can be seen in Table 2.

Table 2. Independent Test Results

\begin{tabular}{|l|l|l|c|}
\hline No & Variable & $\chi_{\text {count }}^{2}$ & $\chi_{\text {table }}^{2}$ \\
\hline 1 & $X_{1}$ and $X_{2}$ & 35,595 & 37,6525 \\
\hline 2 & $X_{1}$ and $X_{3}$ & 34,348 & 37,6525 \\
\hline 3 & $X_{2}$ and $X_{3}$ & 25,548 & 37,6525 \\
\hline
\end{tabular}

3. Linearity Test

Linearity test is used to determine whether the independent variable of learning independence $\left(\mathrm{X}_{1}\right)$, reasoning ability $\left(\mathrm{X}_{2}\right)$ and home learning environment $\left(\mathrm{X}_{3}\right)$ with the dependent variable of mathematics learning outcomes $(\mathrm{Y})$ has a linear relationship or not. Based on the linearity test that has been done, it was found that between learning independence and mathematics learning outcomes, reasoning ability with mathematics learning outcomes, and home learning environment with mathematics learning outcomes, there is a linear relationship. The summary of linearity test results can be seen in Table 3 .

Table 3. Linearity test results

\begin{tabular}{|l|l|l|l|}
\hline No & Variable & $\boldsymbol{F}_{\text {count }}$ & $\boldsymbol{F}_{\text {table }}$ \\
\hline 1 & $\mathrm{X}_{1}$ to $\mathrm{Y}$ & 2,505 & 2,67 \\
\hline 2 & $\mathrm{X}_{2}$ to $\mathrm{Y}$ & 1,366 & 2,76 \\
\hline 3 & $\mathrm{X}_{3}$ to $\mathrm{Y}$ & 0,857 & 2,79 \\
\hline
\end{tabular}


4. Hypothesis testing

Based on the results of the F-test multiple correlation analysis, the correlation coefficient of learning independence $\left(\mathrm{X}_{1}\right)$, reasoning ability $\left(\mathrm{X}_{2}\right)$ and home learning environment $\left(\mathrm{X}_{3}\right)$ were obtained with mathematics learning outcomes $(\mathrm{Y})$ of 0.6950 and results $F_{\text {count }}=20,5041$ while $F_{\text {table }}$ at a significant level of $5 \% \mathrm{df}=\mathrm{n}-3-1=27$, with $\mathrm{n}=31$ which is equal to 2.96 . So that $F_{\text {count }}>F_{\text {table }}$, then the hypothesis has been tested by rejecting $\mathrm{H}_{0,7}$ and accepting $\mathrm{H}_{1,7}$, which means there is a positive and significant relationship between learning independence, reasoning ability, and home learning environment with the mathematics learning outcomes of the student's class XI TKJ students in the even semester of SMK Negeri 1 Pleret, Bantul Regency in 2015 / 2016. Whereas the regression equation is $\widehat{Y}=-19,56+0,4163 X_{1}+0,0999 X_{2}+0,6608 X_{3}$.

5. Relative Contributions (SR\%) and Effective Donations (SE\%)

The relative contribution size (SR\%) and the amount of effective contribution (SE\%) for each variable $\mathrm{X}_{1}, \mathrm{X}_{2}$, and $\mathrm{X}_{3}$ with $\mathrm{Y}$ variables can be seen in Table 4 .

Table 4. Relative Contributions and Effective Donations

\begin{tabular}{|c|c|c|}
\hline Variable & $\begin{array}{l}\text { Relative Donations } \\
(\text { SR\% })\end{array}$ & $\begin{array}{l}\text { Effective Donations } \\
\text { (SE\%) }\end{array}$ \\
\hline$X_{1}$ & $34,44 \%$ & $23,63 \%$ \\
\hline$X_{2}$ & $8,65 \%$ & $6,25 \%$ \\
\hline$X_{3}$ & $56,91 \%$ & $39,62 \%$ \\
\hline Total & $100 \%$ & $69,5 \%$ \\
\hline
\end{tabular}

\section{CONCLUSION}

Based on the results of research and discussion, it can be concluded that: There is a positive and significant relationship between learning independence, reasoning ability, and home learning environment with the mathematics learning outcomes of class XI TKJ students in the even semester of SMK Negeri 1 Pleret, Bantul Regency in 2015 / 2016.

\section{REFERENCES}

Arikunto, Suharsimi. 2010. Prosedur Penelitian Suatu Pendekatan Praktik. Jakarta : Rineka Cipta. Nurhayati, Eti. 2011. Bimbingan, Konseling dan Psikoterapi Inovatif. Yogyakarta: Pustaka Pelajar.

Shadiq, fajar. 2004. Pemecahan Masalah, Penalaran dan Komunikasi. Yogyakarta: Departemen Pendidikan Matematika PPPG Matematika.

Sugiyono. 2016. Metode Penelitian Pendidikan (Kuantitatif, Kualitatif dan $R \& B$ ). Bandung : Alfabeta. 